\title{
Copper Tolerance in Australian Populations of Xanthomonas campestris pv. vesicatoria Contributes to Poor Field Control of Bacterial Spot of Pepper
}

\author{
Heidi L. Martin and Vicki A. Hamilton, Queensland Horticulture Institute, Centre for Vegetable Crops, LMB 7, MS \\ 437, Warrego Hwy, Gatton, Qld. 4343, Australia, and Rosemary A. Kopittke, Queensland Horticulture Institute, \\ Indooroopilly Sciences Centre, 80 Meiers Road, Indooroopilly, Qld. 4068, Australia
}

\begin{abstract}
Martin, H. L., Hamilton, V. A., and Kopittke, R. A. 2004. Copper tolerance in Australian populations of Xanthomonas campestris pv. vesicatoria contributes to poor field control of bacterial spot of pepper. Plant. Dis. 88:921-924.

Many Australian pepper producers have reported poor control of bacterial spot of pepper (caused by Xanthomonas campestris pv. vesicatoria) despite using copper bactericides at recommended rates. This prompted us to investigate whether copper-tolerant strains of the pathogen are present in Australia and whether they are a contributing factor to poor control. We screened strains of $X$. campestris pv. vesicatoria in the laboratory, in broths containing different concentrations of $\mathrm{CuSO}_{4}$, and established the maximum copper concentration at which each strain could grow. About one in four strains ( 75 total) collected between 1999 and 2000 tolerated $\geq 1.0 \mathrm{mM} \mathrm{CuSO}_{4}$ and could be considered copper tolerant. Only one strain (of 12) collected before 1987 could tolerate $1.0 \mathrm{mM}$, and comparison of the two populations by fitting regression models revealed that the mortality of strains in the two populations differed significantly across all concentrations of copper. It was necessary to apply higher rates of copper to strains collected between 1999 and 2000 to achieve mortality levels equivalent to those in the older population. This is strong evidence that the prevalence of copper-tolerant strains has increased in Australian populations. We also assessed whether copper-tolerant strains may increase substantially in a field population of $X$. campestris pv. vesicatoria when copper is repeatedly sprayed. In the field, the proportion of copper-tolerant strains increased after 12 weekly sprays of copper, and they were very prevalent in the population after 21 sprays. This is the first report of copper tolerance in Australian populations of $X$. campestris pv. vesicatoria.
\end{abstract}

In Queensland, Australia, bacterial spot of pepper (caused by Xanthomonas campestris pv. vesicatoria) is a severe disease favored by warm, wet weather. It reduces both fruit yield and quality, and may destroy crops altogether. Effective disease control options are limited, with copper-based bactericides being the only products available to Australian pepper producers to combat bacterial spot. However, since the middle to late 1990s, an increasing number of Queensland producers have reported poor field control of bacterial spot epidemics, despite the routine use of copper bactericides. Several factors may contribute to this poor field control, including poor spray coverage, incorrect timing of copper sprays, or both; the presence of bacterial strains tolerant of copper; or favorable environmental conditions together with high disease pressure. In our study, we tested whether copper-

Corresponding author: Heidi L. Martin

E-mail: Heidi.Martin@dpi.qld.gov.au

Accepted for publication 12 March 2004.

Publication no. D-2004-0712-03R

This article is in the public domain and not copyrightable. It may be freely reprinted with customary crediting of the source. The American Phytopathological Society, 2004. tolerant strains of $X$. campestris pv. vesicatoria are present in Queensland populations and established whether their presence may contribute to poor disease control. We considered this aspect worth investigating because the frequency with which copper tolerance is being reported in populations of plant-pathogenic bacteria in general seems to have increased since the 1980s $(1,2,4,12-14)$. In particular, strains of $X$. campestris pv. vesicatoria with tolerance to copper have been associated with disease outbreaks and severe losses in pepper crops sprayed with copper in many countries outside Australia, including the United States (9), Taiwan (7), Korea (8), Barbados (6), and Mexico (3). In addition to the possibility that copper-tolerant strains may have developed in Australia in response to regular copper usage, the introduction of exotic copper-tolerant strains in seed from outside Australia poses a real threat, since there are no quarantine barriers to importing pepper seed into Australia.

The copper tolerance of plantpathogenic bacteria in Australia is open to speculation. A single study of copper tolerance in Australian populations of Pseudomonas syringae pv. tomato has been published (15), but the status of copper tolerance in $X$. campestris pv. vesicatoria remains unknown. Our investigation sought to remedy this deficiency. We estab- lished that $X$. campestris pv. vesicatoria strains tolerant of copper do exist in Queensland and that, in the field, after repeated exposure to copper, they may become extremely prevalent in a population.

\section{MATERIALS AND METHODS}

Isolation of $X$. campestris pv. vesicatoria. Pepper and chili plants with bacterial spot were collected from 28 farms across Queensland in 1999-2000. Isolations were made from infected leaves, stems, and fruit by macerating small pieces of symptomatic tissue in drops of sterile deionized water and streaking the macerate onto nutrient agar. Cultures were incubated at $28^{\circ} \mathrm{C}$ for $48 \mathrm{~h}$, and characteristic colonies were restreaked twice to ensure purity. Only gram-negative cultures were used. We used a commercial test kit, based on a specific agglutination test reaction, to identify the strains as $X$. campestris pv. vesicatoria (Adgen Ltd., Ayr, Scotland). To confirm pathogenicity, inoculum suspensions $\left(10^{8} \mathrm{CFU} / \mathrm{ml}\right)$ were misted onto young plants of Capsicum annuum cv. Heldor, a cultivar with no resistance to bacterial spot. Plants were incubated under high humidity for $48 \mathrm{~h}$, and the bacterium was reisolated from symptomatic plant tissue. Bacteria were preserved in Cryobank (Mast Diagnostics, Bootle, U.K.) vials stored at $-20^{\circ} \mathrm{C}$, and lyophilized cultures of each strain were also prepared.

Seventy-five strains of $X$. campestris pv. vesicatoria were collected in this study. Most of these (61) were from north Queensland (Burdekin 21; Gumlu 22; Bowen 18), four were from central Queensland (Bundaberg), and 10 were from south Queensland (Lockyer Valley and Stanthorpe). In addition, 12 strains were retrieved from Australian herbarium collections (DAR26930, DAR26931, DAR26932， DAR26933， DAR33341, DAR34895a, BRIP39063, BRIP38988, BRIP38998, BRIP38999, BRIP39009, GRS1910). These 12 strains, collected between 1972 and 1986, were used to generate baseline information about copper tolerance in Australian populations of $X$. campestris pv. vesicatoria before 1987. Comparing the copper tolerance in strains collected in 1999 and 2000 with this baseline from the older strains allowed changes in the sensitivity to copper of Australian $X$. campestris pv. vesicatoria populations to be measured. 
Copper-tolerance screening. Bacteria were grown on nutrient agar for $72 \mathrm{~h}$, and a single colony was selected from each culture and inoculated into a flask containing $25 \mathrm{ml}$ of sterile casitone yeast-extractglycerol broth. Each flask was shaken on a platform orbital shaker (130 rpm) for $24 \mathrm{~h}$. Aliquots $(1.0 \mathrm{ml})$ from each flask were then inoculated into a set of eight flasks of casitone yeast-extract-glycerol broth, with one flask amended with a concentration of $\mathrm{CuSO}_{4} \cdot 5 \mathrm{H}_{2} \mathrm{O}(0,0.2,0.3,0.5,0.7,1.0,1.1$, or $1.2 \mathrm{mM} \mathrm{CuSO} \cdot 5 \mathrm{H}_{2} \mathrm{O}$ ). All flasks were shaken on a platform orbital shaker (130 $\mathrm{rpm}$ ) for $48 \mathrm{~h}$ at $25^{\circ} \mathrm{C}$. A dilution series ( $10^{-8}$ - to $10^{-1}$-fold dilutions) was prepared for each flask in sterile phosphate buffer, and $1.0 \mathrm{ml}$ of each dilution was spread evenly across a plate of nutrient agar. Cultures were incubated at $28^{\circ} \mathrm{C}$ for $72 \mathrm{~h}$, after which resulting bacterial colonies were counted. The highest concentration of $\mathrm{CuSO}_{4} \cdot 5 \mathrm{H}_{2} \mathrm{O}$ at which bacterial colonies formed was determined for each strain. The response of strains collected before 1987 (12 in total) was compared with strains collected between 1999 and 2000 (75 in total). Data were analyzed using a GLM to relate mortality and copper concentration using Genstat 6 for Windows (Lawes Agricultural Trust, Rothamsted, England). Six different regression models (dose response curves) were fitted, and we determined that the complementary log-log link without a $\log$ transformation of the copper concentration provided the best fit (using the residual deviance to compare the goodness of fit of the models).

Field assessment of copper-tolerance development in an $X$. campestris pv. vesicatoria population. Pepper seedlings were planted into the field, plots (treatment) and buffer (unsprayed) areas were marked, and, to provide an inoculum source, we replaced the healthy plants in the buffer areas adjoining each plot with seedlings infected with bacterial spot. Seedlings of pepper cv. Heldor were spaced $15 \mathrm{~cm}$ apart in single rows on beds $60 \mathrm{~m}$ long $\times 1.5 \mathrm{~m}$ wide with overhead irrigation. A randomized complete block design was used, with three blocks each containing three treatments (Kocide DF, a Kocide DF and Mancozeb WG tank-mix combination, and unsprayed [control]). Plots were $3 \mathrm{~m}$ long and were bordered at either end by buffer plots, each $2 \mathrm{~m}$ long. To minimize cross contamination of plots by spray drift, whole rows of buffer plants were also positioned between the rows containing treated plots. The plants transplanted into the buffer plots as a source of inoculum were misted with a bacterial suspension of $X$. campestris pv. vesicatoria $\left(10^{8} \mathrm{CFU} / \mathrm{ml}\right)$ and incubated under high humidity for $48 \mathrm{~h}, 1$ week before being transplanted. The inoculum suspension contained equal quantities of six strains with tolerances to copper ranging between 0 and $1.0 \mathrm{mM}$. Kocide DF (2.0 kg/ha) and the combination of Kocide DF (2.0 kg/ha) and Mancozeb WG (2.0 kg/ha) were sprayed every 7 days from a motorized backpack spray rig fitted with a 1-m boom and four hollow-cone nozzles. Unsprayed plots were the controls in the experiment. Treatments commenced 2 weeks after transplanting and continued for 21 weeks. Two plants were tagged in each plot, and, after four sprays, the two youngest leaves on each tagged plant with symptoms of bacterial spot were removed.

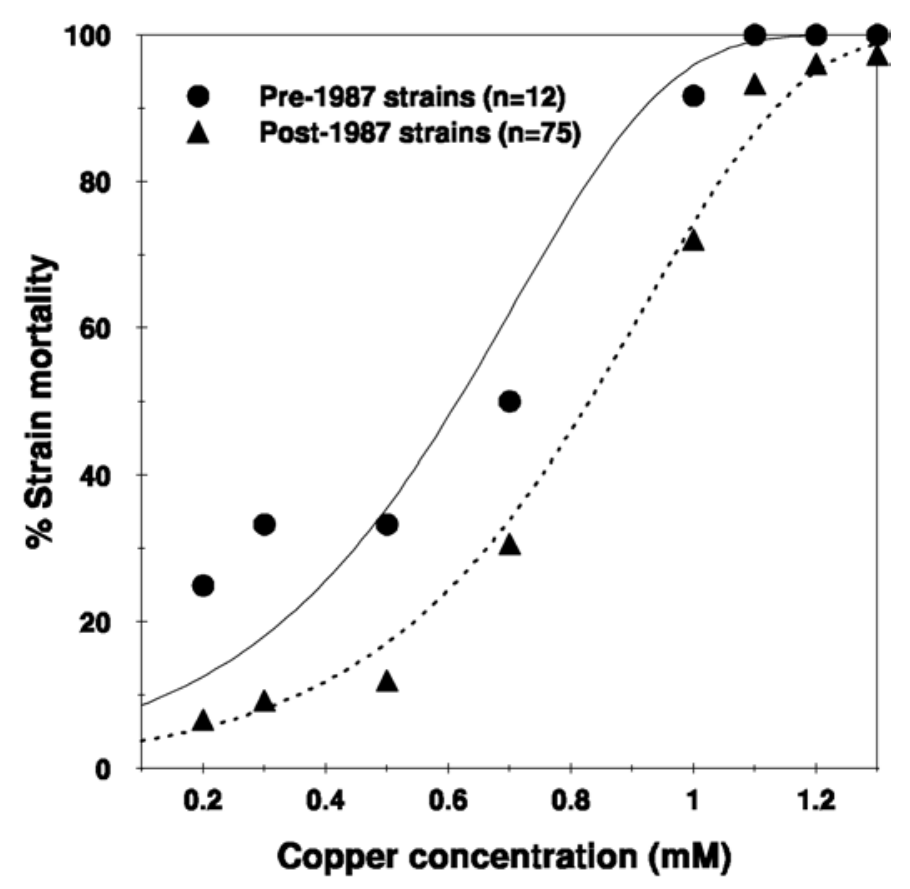

Fig. 1. A larger proportion of young isolates could tolerate 1.0-mM copper compared with older isolates, and only young isolates could tolerate copper concentrations of $1.1 \mathrm{mM}$ or higher.

Suspensions from every lesion on each leaf were plated onto nutrient agar, pure cultures were obtained and determined to be gram-negative, and the identity of each strain was confirmed to be $X$. campestris pv. vesicatoria by using a bacterial detection kit (Adgen Ltd.). Each strain was then screened for tolerance to copper in vitro by following the protocol described in the preceding section. Sampling was repeated after 12 sprays and again after 21 sprays. In total, 49 strains were cultured from leaves collected after 4 sprays, 133 from leaves after 12 sprays, and 129 from leaves after 21 sprays. Each time in each plot, the percentage of the bacterial population tolerant to each copper concentration was determined. Because the percentage of strains tolerant to the copper concentrations was based on unequal numbers of lesions at each point, the percent tolerance was analyzed in Genstat 6 (Lawes Agricultural Trust) as an unbalanced randomized block design split for time (using the number of lesions as weights). Comparisons between treatments were done using Fisher's protected least significant difference (LSD).

\section{RESULTS}

Copper-tolerance screening. None of the strains collected before 1987 survived at copper concentrations exceeding 1.0 $\mathrm{mM}$, whereas nearly $7 \%$ (5/75) of the more recent strains did (Fig. 1).

The regression analysis indicated that the interaction between the pre- and post1987 populations and copper concentration was not significant $(P=0.191)$, demonstrating that both populations responded similarly to increased concentrations of copper. There were, however, significant differences between the two populations ( $P$ $<0.001)$. The relationship between the mortality and copper concentration for each population is described by the parallel lines:

$Y_{\text {pre-1987 }}=-2.803+3.957$ Concentration $Y_{\text {post-1987 }}=-3.650+3.957$ Concentration

where $p=$ proportion of strains killed, and $Y=\ln [-\ln (1-p)]=\operatorname{CLL}(p)$, the complementary log-log transform of $p$

The results demonstrate that, across the range of concentrations, the post-1987 strains required a concentration of copper $0.214 \mathrm{mM}$ higher (95\% confidence interval: 0.103 to $0.323 \mathrm{mM}$ ) than the pre-1987 strains to achieve the same level of strain mortality (Fig. 1).

We found that $X$. campestris pv. vesicatoria populations from Gumlu and Bowen contained strains tolerant of copper concentrations 6.5 times greater than the lowest lethal copper concentration studied $(0.2$ $\mathrm{mM}$ ) (Fig. 2). This result is probably not coincidental, because both Gumlu and Bowen are areas of intensive production where populations are likely to be exposed 
to intensive spraying. Strains tolerant of were not recovered from any other district.

Field assessment of copper-tolerance development in an $X$. campestris pv. vesicatoria population. Disease pressure was extremely high in this trial following warm showery weather. Repeated spraying caused a shift in copper tolerance. At the lowest copper concentration $(0.2 \mathrm{mM})$, the interaction between number of sprays and copper concentrations in excess of $1.0 \mathrm{mM}$

treatment type was not significant $\left(F_{4,10}=\right.$ 2.31, $P=0.129$ ), indicating that although the mean percentages of strains tolerant to 0.2-mM copper were different among treatments (Kocide $60.2 \%$, Kocide + Mancozeb $77.7 \%$, untreated $51.7 \%$ ), the bacterial populations sprayed with each treatment responded similarly after equivalent numbers of sprays. The number of sprays applied did, however, significantly alter the proportion of the bacterial populations that

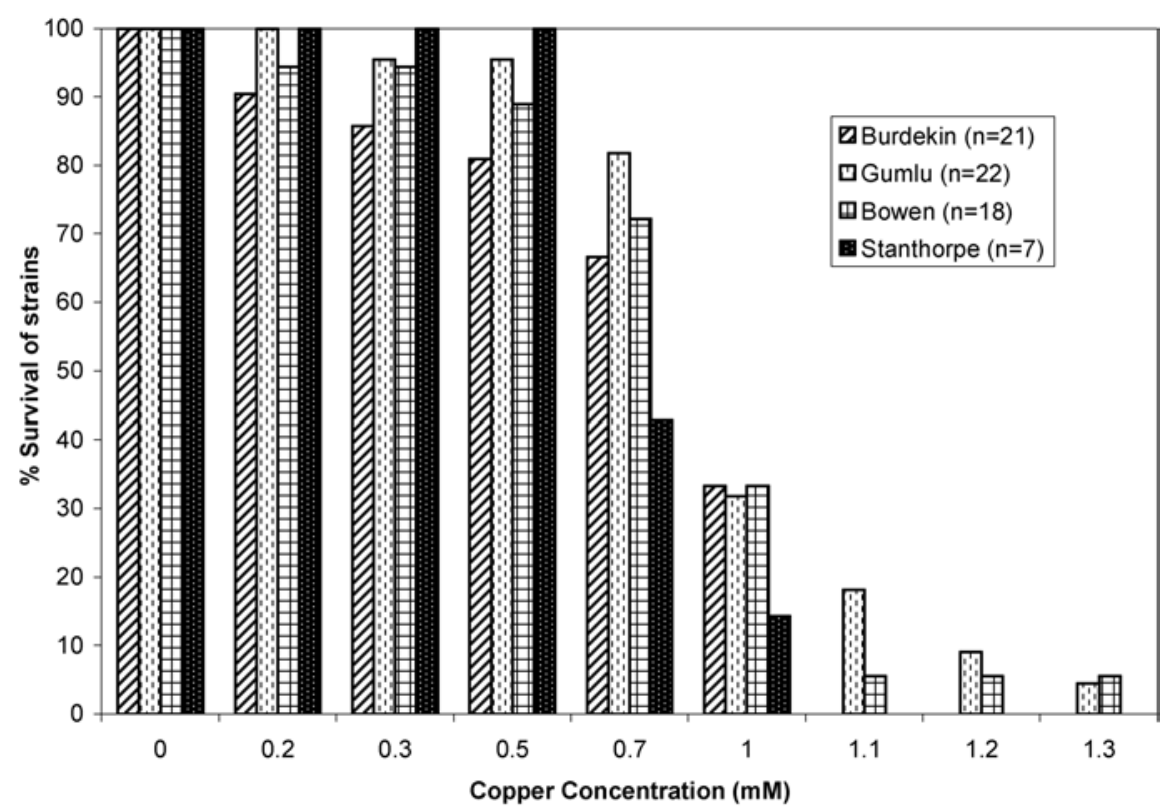

Fig. 2. Populations of Xanthomonas campestris pv. vesicatoria from Gumlu and Bowen contain strains more tolerant of copper than populations from other districts.

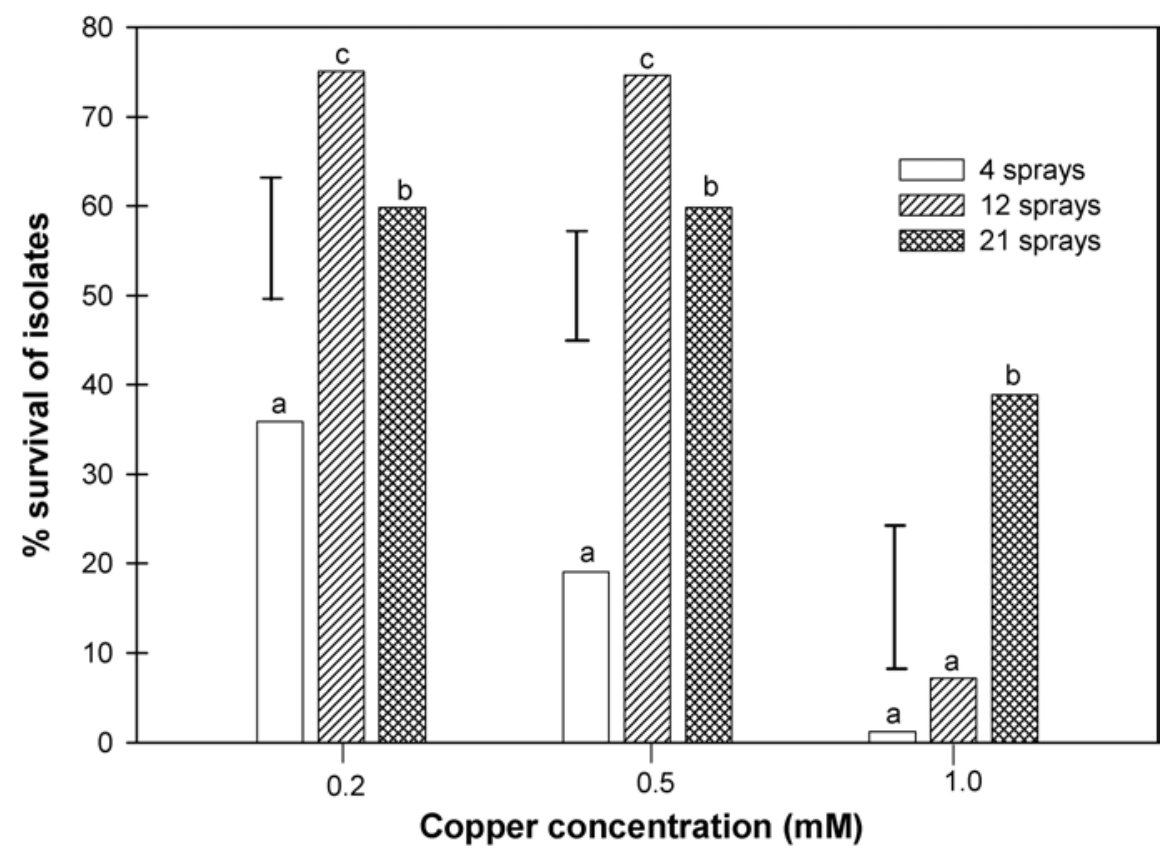

Fig. 3. Nearly half of the isolates of Xanthomonas campestris pv. vesicatoria in a field population are copper tolerant after 21 copper sprays, compared with only about $1 \%$ of the population after 4 sprays. Bars are average LSD values and refer to comparisons within concentrations, as do the letters $a, b$, and c. Treatments with the same letters are not significantly different at the $5 \%$ level. Average LSDs are presented, but comparisons between treatments were made using exact LSD values. Data for $0.7 \mathrm{mM}$ were not presented, since at this concentration there was a significant interaction between treatment and number of sprays (Table 1). could tolerate $0.2-\mathrm{mM}$ copper $\left(F_{2,10}=\right.$ $8.08, P<0.001)$. For the first four sprays, the bacterial populations remained sensitive to $0.2-\mathrm{mM}$ copper, with only $35.9 \%$ of strains surviving at this concentration compared with $\geq 60.0 \%$ of strains collected after 12 and 21 applications (Fig. 3). Similarly, for $0.5-\mathrm{mM}$ copper, the interaction between number of sprays and treatment type was not significant $\left(F_{4,10}=3.15, P=\right.$ 0.064 ), but the percentage of strains tolerant of $0.5-\mathrm{mM}$ copper did increase significantly if more sprays were applied $\left(F_{2,10}=\right.$ 41.40, $P<0.001$ ) (Fig. 3). Copper-tolerant strains became increasingly more common in the population after more sprays, as demonstrated by the results for the 1.0$\mathrm{mM}$ copper concentration (Fig. 3). The interaction between treatment and number of sprays was again not significant $\left(F_{4,10}=\right.$ $1.35, P=0.319)$, although the effect of increasing the number of spray applications was significant $\left(F_{2,10}=19.85, P<\right.$ 0.001). After four copper sprays, only $1.2 \%$ of strains tolerated copper concentrations of $\geq 1.0 \mathrm{mM}$, whereas, after 12 sprays, this had increased to $7.2 \%$ of strains. After 21 sprays, copper-tolerant strains were prevalent in the population, with $38.9 \%$ of strains tolerant of copper concentrations of $1.0 \mathrm{mM}$ or higher.

At a copper concentration of $0.7 \mathrm{mM}$, there was a significant $\left(F_{4,10}=9.44, P=\right.$ 0.002 ) interaction between the number of sprays and specific treatments (Table 1). After 21 sprays, plots treated with Kocide DF or the combination of Kocide DF and Mancozeb WG yielded significantly $(P<$ 0.05 ) higher proportions (60.5 and $67.9 \%$, respectively) of strains that were tolerant of $0.7-\mathrm{mM} \mathrm{CuSO} \mathrm{Cu}_{4} \cdot 5 \mathrm{H}_{2} \mathrm{O}$, compared with only $26.5 \%$ of strains from untreated plots. The proportions of strains that were tolerant of copper were equivalent in plots treated with Kocide DF or the Kocide DF and Mancozeb WG combination. At 1.2 $\mathrm{mM}$, no strains survived after 4 and 12 sprays; however, by 21 sprays tolerance was evident in all treatments, with $33.8 \%$ of strains treated with Kocide DF and $36.5 \%$ of those treated with the combination of Kocide DF and Mancozeb WG being tolerant compared with only $9.7 \%$ of strains recovered from untreated plots.

Table 1. The percentage of Xanthomonas campestris pv. vesicatoria strains tolerant of 0.7-mM copper increased significantly in populations sprayed repeatedly with Kocide DF or a combination of Kocide DF and Mancozeb WG

\begin{tabular}{lccc}
\hline & \multicolumn{3}{c}{ Number of sprays $^{\mathbf{z}}$} \\
\cline { 2 - 4 } Treatment & $\mathbf{4}$ & $\mathbf{1 2}$ & $\mathbf{2 1}$ \\
\hline Kocide DF & $0 \mathrm{a}$ & $29.8 \mathrm{~b}$ & $60.5 \mathrm{c}$ \\
Kocide DF + & $8.3 \mathrm{a}$ & $28.1 \mathrm{~b}$ & $67.9 \mathrm{c}$ \\
Mancozeb WG & & & \\
Untreated & $0 \mathrm{a}$ & $31.1 \mathrm{~b}$ & $26.5 \mathrm{~b}$ \\
Average LSD (5\%) & & 16.4 & \\
\end{tabular}

${ }^{\mathrm{z}}$ Means followed by the same letter are not significantly different at the $5 \%$ level. 


\section{DISCUSSION}

This study records the presence of copper-tolerant strains of $X$. campestris pv. vesicatoria in Australia for the first time. This finding, and our experimental evidence that copper-tolerant strains may increase substantially in a field population after repeated sprays of copper, are the most important results of this investigation.

Several methods for determining copper tolerance in bacteria have been documented in the literature. For example, strains of $X$. campestris pv. vesicatoria from Barbados were identified as being resistant to copper if they produced confluent growth on nutrient agar amended with copper sulfate at $200 \mu \mathrm{g} / \mathrm{ml}(0.80$ $\mathrm{mM}$ ) (6). In Australia, strains of $P$. syringae pv. tomato were characterized as being copper tolerant on the basis of growth on casitone yeast-extract-glycerol agar amended with 0.6 to $1.2 \mathrm{mM} \mathrm{CuSO}_{4}$, and being resistant at concentrations greater than $1.6 \mathrm{mM}$ (15). However, because the toxicity of heavy metals toward microorganisms depends on the chemical state in which they exist, and in particular the free metallic ion concentration $(10,16)$, we thought it more appropriate to screen strains in broth culture rather than on solid media. Our rationale for this choice was that, in broth, the entire bacterial cell is potentially exposed to the toxic action of the copper, whereas this is not the case on solid agar media. In our study, we used a low-complexing casitone yeast-extractglycerol broth medium because of its minimal tendency to bind the copper to components of the medium (16). This medium was suited to determining $\mathrm{Cu}^{2+}$ ion sensitivity, because, when added to the medium, most of the copper remained in the ionic form, thus ensuring maximum toxicity to the bacteria.

Copper-resistant bacterial strains have been demonstrated to survive at $1.0-\mathrm{mM}$ $\mathrm{CuSO}_{4}$ in this medium (16). In our study, $28.0 \%$ of strains $(21 / 75)$ tolerated $\mathrm{CuSO}_{4}$ concentrations of $1.0 \mathrm{mM}$ or more. If the copper-tolerance assessments of the previous studies are taken into account, our strains should be regarded at being copper tolerant, if not copper resistant.

We have also clearly shown that copper tolerance has increased within the last 15 years in Queensland populations. It seems likely on the basis of this result that copper-tolerant strains of $X$. campestris pv. vesicatoria may be contributing to the lack of efficacy of copper sprays in controlling recent epidemics of bacterial spot in Queensland. Since all commercially grown pepper seed is imported into Australia, and with the development of copper tolerance being such a recent phenomenon, it is tempting to surmise that seed lots contaminated with copper-tolerant strains of the bacterium were the most likely source of initial introduction into Australia.
From the standpoint of management of copper-tolerant strains, our finding that tolerant strains constituted nearly $40 \%$ of a bacterial spot population after 21 exposures to copper becomes particularly important. In situations when temporal and spatial separation of pepper crops is not possible, particularly within major production districts, there almost certainly will be an increased risk of disease carry-over between crops. In these instances, it is likely that the bacterial population will be exposed to many copper applications, thus increasing the likelihood that the population will become dominated by coppertolerant strains.

This scenario may partly explain why, in our study, the strains tolerant of the highest copper concentrations were from crops in the Gumlu district of north Queensland. This district has highly intensive pepper production, with many farms close to one another. Because of this, it is highly probable that any bacterial spot population present in Gumlu is likely to spread through sequential crops or onto neighboring farms. With many producers spraying copper, it is likely that the population will be exposed to many copper applications during the season, potentially leading to an increased prevalence of copper-tolerant strains.

In this experiment, the percentages of copper-tolerant strains recovered from plots sprayed with Kocide DF and the Kocide DF + Mancozeb WG combination were equivalent. This result was surprising because other researchers have reported combinations of copper and carbamate fungicide to be superior to copper alone for controlling copper-tolerant strains of $X$. campestris pv. campestris $(9,11)$. The mechanism for this enhancement of toxicity through the addition of carbamate fungicides to copper is not clear; however, one suggestion is that when carbamate fungicides are combined with copper, they may increase the availability of toxic copper ions in solution (5). If this mechanism is correct, we can only assume that in our experiment the quantity of mancozeb supplied was insufficient to release enough additional cupric ions to kill the tolerant strains.

Our study has provided clear evidence that copper-tolerant strains of $X$. campestris pv. vesicatoria are present in Australian populations of bacterial spot of pepper, and it is probable that they are contributing to the current failure to control this disease by spraying copper at recommended rates. We have shown that these tolerant strains rapidly increase in a population when copper is sprayed repeatedly. Copper tolerance represents a new hindrance to effective management of bacterial spot in Australian pepper crops, as any management strategy will now need to involve measures to minimize copper tolerance.
ACKNOWLEDGMENTS

We thank Robert Davis, Scott Boreel, Gerry MacManus, and Leigh Barker for technical input. Sincere thanks also to Robert Brown for his valuable comments on the manuscript.

\section{LITERATURE CITED}

1. Alexander, S. A., Kim, S. H., and Waldenmaier, C. M. 1999. First report of coppertolerant Pseudomonas syringae pv. tomato in Virginia. Plant Dis. 83:964.

2. Andersen, G. L., Menkissoglou, O., and Lindow, S. E. 1991. Occurrence and properties of copper-tolerant strains of Pseudomonas syringae isolated from fruit trees in California. Phytopathology 81:648-656.

3. Carrillo-Fasio, J. A., Garcia-Estrada, R. S., Allende-Molar, R., Marquez-Zequera, I., Millan-Ocampo, S., and Gaxiola-Espinoza, G. 2001. Sensitivity of Xanthomonas campestris pv. vesicatoria (Doidge) Dye strains to copper. Rev. Mex. Fitopatol. 19:72-77.

4. Cazorla, F. M., Arrebola, E., Sesma, A., PerezGarcia, A., Codina, J. C., Murillo, J., and de Vicente, A. 2002. Copper resistance in Pseudomonas syringae strains isolated from mango is encoded mainly by plasmids. Phytopathology 92:909-916.

5. Cooksey, D. A. 1990. Genetics of bactericide resistance in plant pathogenic bacteria. Annu. Rev. Phytopathol. 28:201-219.

6. Gore, J. P., and O'Garro, L. W. 1999. Xanthomonas campestris pv. vesicatoria from bell pepper and tomato in Barbados undergoes changes in race structure, virulence and sensitivity to chemical control agents. J. Phytopathol. 47:397-402.

7. Hseu, S. H., and Hsu, S. T. 1991. Sensitivity of strains of Xanthomonas campestris pv. vesicatoria from Taiwan to copper and other agrochemicals. Plant Prot. Bull. (Taipei) 33:410419.

8. Lee, S. D., and Cho, Y. S. 1996. Copper resistance and race distribution of Xanthomonas campestris pv. vesicatoria on pepper in Korea. Korean J. Plant Pathol. 12:150-155.

9. Marco, G. M., and Stall, R. E. 1983. Control of bacterial spot of pepper initiated by strains of Xanthomonas campestris pv. vesicatoria that differ in sensitivity to copper. Plant Dis. 67:779-781.

10. Menkissoglu, O., and Lindow, S. E. 1991 Relationship of free ionic copper and toxicity to bacteria in solutions of organic compounds. Phytopathology 81:1258-1263.

11. Ritchie, D. F., and Bennett, M. H. 1991. Impact of copper and additives to copper on pepper yield in the presence of copper-sensitive and -resistant bacterial pathogen strains. Fungic. Nematicide Tests 47:105.

12. Scheck, H. J., and Pscheidt, J. W. 1998. Effect of copper bactericides on copper-resistant and -sensitive strains of Pseudomonas syringae pv. syringae. Plant Dis. 82:397-406.

13. Scheck, H. J., Pscheidt, J. W., and Moore, L. W. 1996. Copper and streptomycin resistance in strains of Pseudomonas syringae from $\mathrm{Pa}$ cific Northwest nurseries. Plant Dis. 80:1034 1039.

14. Sholberg, P. L., Bedford, K. E., Haag, P., and Randall, P. 2001. Survey of Erwinia amylovora isolates from British Columbia for resistance to bactericides and virulence on apple. Can. J. Plant Pathol. 23:60-67.

15. Tesoriero, L., Warren, M., and Minchinton, E. 1997. Copper resistance in Australian isolates of Pseudomonas syringae pv. tomato. Page 311 in: Proc. Australas. Plant Pathol. Soc. 11th Bienn. Conf., Perth.

16. Zevenhuizen, L. P. T. M., Dolfing, J., Eshuis, E. J., and Scholten-Koerselman, I. J. 1979. Inhibitory effects of copper on bacteria related to the free ion concentration. Microb. Ecol. 5:139-146. 